\title{
M. Strasser • M. Walensky • K. Reise \\ Juvenile-adult distribution of the bivalve Mya arenaria on intertidal flats in the Wadden Sea: why are there so few year classes?
}

Received: 18 June 1998 / Accepted: 12 November 1998

\begin{abstract}
Patchy distribution is frequently observed in benthic marine invertebrates. In order to indentify factors causing spatial patterns in the bivalve Mya arenaria, abundances of juveniles and adults, as well as death assemblages, were recorded on a $20-\mathrm{km}$ scale in the intertidal zone of the Sylt-Rømø Bight. Both adults and juveniles exhibited pronounced patchiness. Shell length of juveniles rarely exceeded $2 \mathrm{~mm}$ in 1995, which was most likely a consequence of epibenthic predators truncating the size spectrum. Only a few yearclasses dominated the adult population. While the northern part of the Bight was colonized mainly by a 1993 -cohort, most $M$. arenaria in the southern part were from the mid-1980s. It is hypothesized that epibenthic predation is a major cause of the lack of dense $M$. arenaria beds from other years. However, examination of the length-frequency distribution of death assemblages revealed that other unidentified causes of mortality exist. High abundances of adults were found in the mid and lower intertidal zone but not in the high intertidal zone. There was no indication that dispersal of $M$. arenaria spat in a landward or seaward direction contributed significantly to the observed distribution pattern, since spat occurred abundantly at all tidal levels except in the high intertidal zone. There was no evidence of negative adult-juvenile interaction. $M$. arenaria was not attracted by seagrass or projecting shell beds - the latter indicating erosion of the sediment - as abundances of adults and juveniles were generally low in these habitats. The effects of sediment type and of the bioturbating lugworm Arenicola marina were inconsistent. While adults were more abundant on muddy sand than on sand, recruitment was independent of sediment type. At all high density sites of adults $\left(>50\right.$ ind $\left.\mathrm{m}^{-2}\right)$, lugworm densities were below 5 ind $\mathrm{m}^{-2}$, which may indicate a negative interaction. However, lugworm densi-
\end{abstract}

M. Strasser $(\bullet) \cdot$ M. Walensky $\cdot$ K. Reise

Wadden Sea Station Sylt, Alfred-Wegener-Institute for Polar

and Marine Research, D-25992 List, Germany

e-mail: mstrasser@awi-bremerhaven.de

Tel.: 49-4651-956-0; Fax: +49-4651-956-200 ties $>30$ ind $\mathrm{m}^{-2}$ did not prevent relatively high $M$. arenaria recruitment of $>500$ ind $\mathrm{m}^{-2}$.

Key words Mya arenaria P Predation · Recruitment . Population dynamics · Patchiness

\section{Introduction}

Population structure and dynamics of Mya arenaria L. in the European Wadden Sea are characterized by the occurrence of adults in locally restricted dense beds (Kühl 1955) and by a large annual variation in reproductive success (Beukema 1982, 1992). Patchy distribution of adult $M$. arenaria is also reported from the Swedish west coast (Möller and Rosenberg 1983) and the east coast of North America (Brousseau 1978; Emerson et al. 1988). Differential reproductive success in $M$. arenaria may in part be explained by low recruitment after mild winters and heavy spatfall after severe winters (Kühl 1955; Beukema 1982, 1992; Reise 1987). However, low recruitment after the cold winter of 1986 shows that reproductive success cannot be predicted by winter temperature alone (Günther 1992).

In general, distribution patterns of benthic organisms with pelagic larvae are shaped by pre- and post-settlement processes. Concerning pre-settlement processes, Kühl (1981) stated that $M$. arenaria is capable of testing the substrate before settlement. This is supported by a large body of literature in which sediment preferences of $M$. arenaria spat were found. However, these results are inconsistent. For example, silty sediment was preferred in some field studies (Reise 1987; Günther 1992), coarser substrates in others (Brousseau and Baglivo 1988; Beal 1989), or no particular substrate at all (Smidt 1951). Contradicting results were likewise reached on adult-larval interactions. Total bivalve spat was reduced by high numbers of adult $M$. arenaria and Cerastoderma edule (L.) in an experimental arrangement on the Swedish west coast (André and Rosenberg 1991), but numbers of $M$. arenaria recruits were not affected by 
dense beds of $M$. arenaria in the Wadden Sea (Kühl 1955; Günther 1992).

Among post-settlement processes, predation has been identified as an important regulator of community structure of infaunal invertebrates including $M$. arenaria (e.g. Pihl 1982; Jensen and Jensen 1985; Reise 1985; Günther 1992). Although young post-larval $M$. arenaria have the potential for dispersal by byssus drifting (Armonies 1994), this was of minor importance for the distribution pattern of $M$. arenaria recruits in the German Bight (Günther 1990). However, on exposed sandy flats, juvenile clams may be dislocated by bedload sediment transport (Emerson and Grant 1991; Armonies 1998). Other physical and biological disturbances may occasionally affect $M$. arenaria populations. $M$. arenaria disappeared from the Danish Wadden Sea after severe winters in the early 1940s (Smidt 1944). Ice scouring reportedly killed $M$. arenaria spat living close to the upper part of the sediment surface, while deeper living adult specimens remained largely unaffected (Kühl 1951). The lugworm, Arenicola marina (L.), a dominant bioturbator on the intertidal flats of the Wadden Sea, was found to have an adverse effect on $M$. arenaria recruitment in a field experiment (Flach 1992).

Fig. 1A,B Mean abundance of Mya arenaria in the intertidal zone north of Røm $\varnothing$ harbor, northern Wadden Sea, in 1995. For better visualization of the sampling sites the intertidal zone below the dotted line is enlarged by $110 \%$. A Adults. B Juveniles. At permanent sites (RI, RII, RIII) abundances are averaged over five sampling dates between July and September 1995

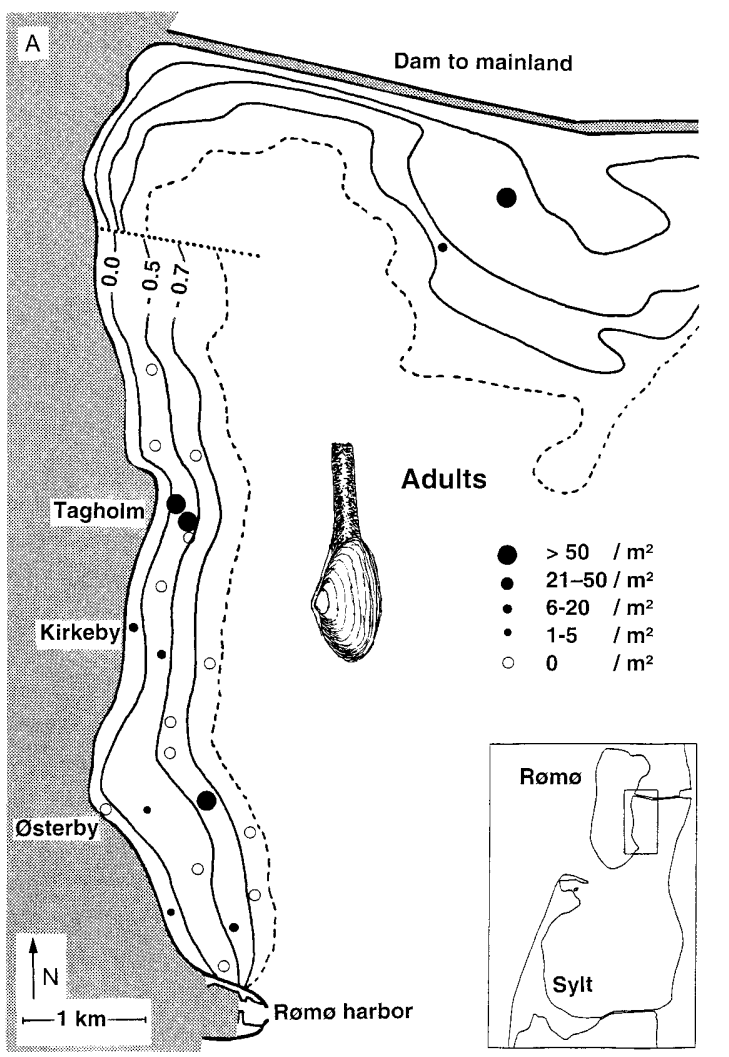

In conclusion, several processes are known to have a strong potential to shape the population structure of $M$. arenaria. Here we examined the relative importance of some of these factors on a large scale (about $20 \mathrm{~km}$ ). The aim of this study was (1) to determine abundances and distribution of adults and spat, as well as death assemblages, as a prerequisite to investigating whether (2) adult $M$. arenaria beds have an adverse effect on the abundance of spat and whether (3) the distribution patterns of spat and adults of $M$. arenaria are influenced by tidal level, sediment type, A. marina density, the presence or absence of seagrass, and projecting $M$. arenaria shells.

\section{Materials and Methods}

Sampling took place in the Sylt-Rømø Bight, a shallow tidal basin in the North Sea, $54^{\circ} 50^{\prime}-55^{\circ} 10^{\prime} \mathrm{N} ; 8^{\circ} 20^{\prime}-8^{\circ} 40^{\prime} \mathrm{E}$. The Bight is bound on two sides by two barrier islands, and their respective causeways to the mainland. The water exchange between the Bight and the North Sea is confined to a narrow tidal inlet between the islands. Here, maximum tidal current velocities are about $1.3 \mathrm{~m} \mathrm{~s}^{-1}$. The Sylt-Røm $\varnothing$ Bight encloses $404 \mathrm{~km}^{2}$, of which one third belongs to the intertidal zone. This zone consists largely of sand flats $(72 \%)$ and to a lesser extent of muddy sand $(25 \%)$ and mud flats (3\%). The low water volume of the Bight is about $570 \times 10^{6} \mathrm{~m}^{3}$ and is doubled at high tide to a volume of about $1120 \times 10^{6} \mathrm{~m}^{3}$. The tides are semi-diurnal with a mean tidal range of about $2 \mathrm{~m}$. Salinity normally remains close to $30 \mathrm{psu}$. Mean annual water temperature is $9{ }^{\circ} \mathrm{C}$ with a summer average of $14{ }^{\circ} \mathrm{C}$ and a winter average of $5{ }^{\circ} \mathrm{C}$. Localized water circulation patterns are generated by the flood and ebb tides in combination with changing wind conditions. More about the area is given in Gätje and Reise (1998).

Spat, adults, and death assemblages of $M$. arenaria were sampled along the east coasts of the islands $R \varnothing m \varnothing$ (northern part of

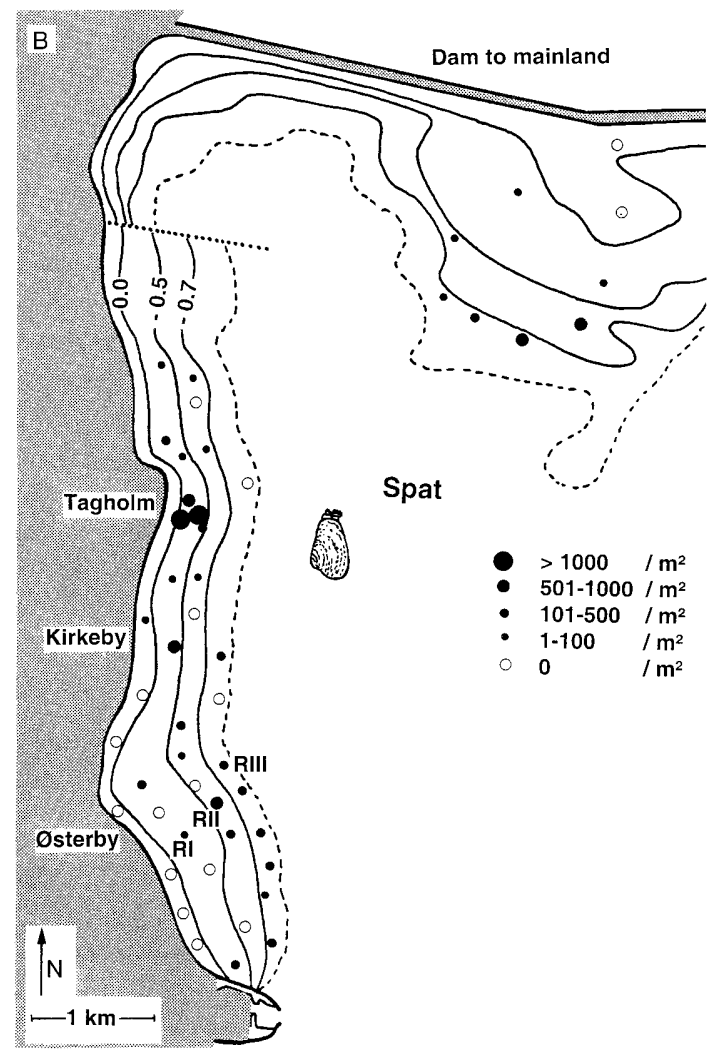



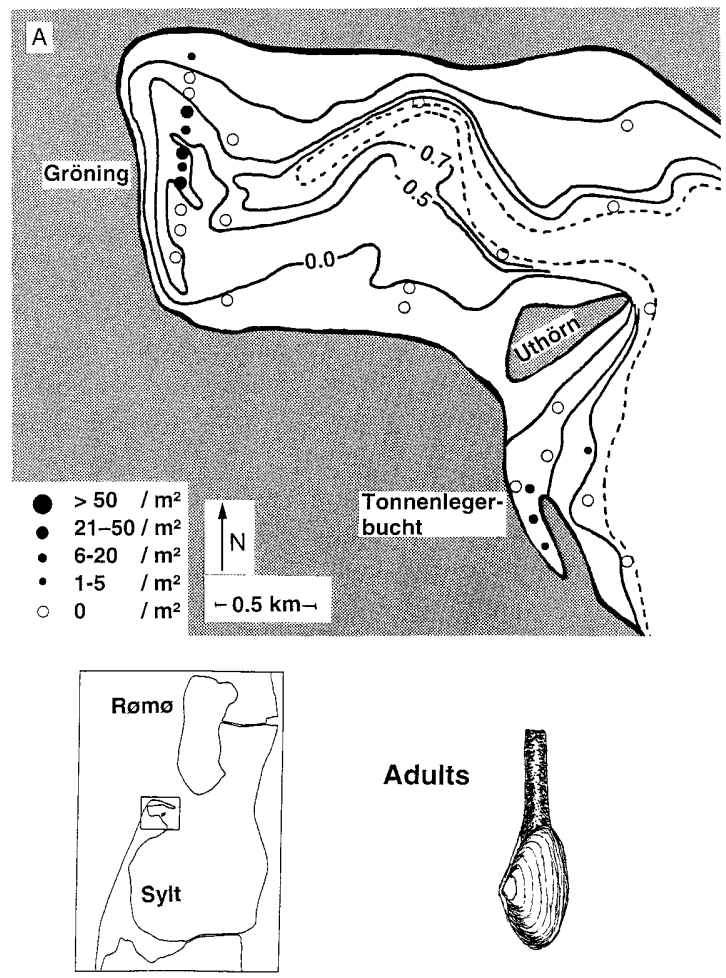

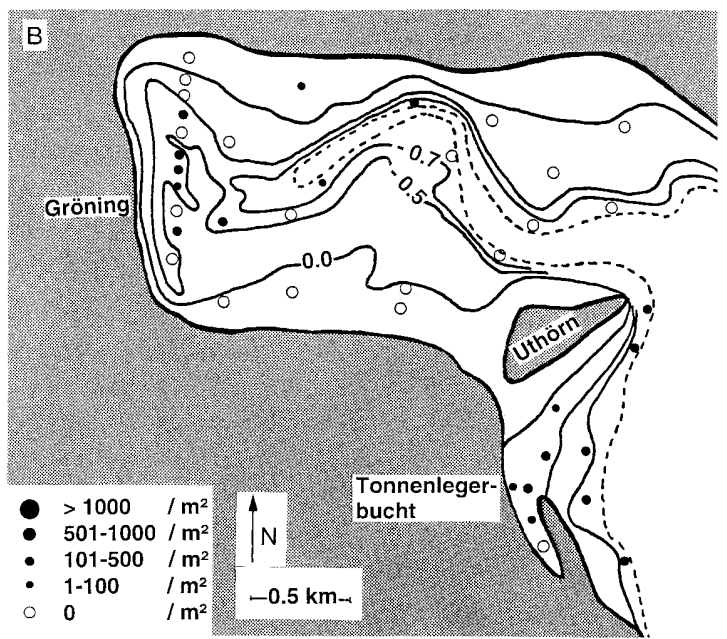

Spat

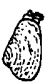

Fig. 2A,B Mean abundance of $M$. arenaria in the intertidal zone of Königshafen Bay, northern Wadden Sea, in 1995. A Adults; B juveniles

al level (MTL), (2) mid-intertidal zone: -0.5 to 0.0 MTL, (3) upper low intertidal zone: -0.7 to $-0.5 \mathrm{MTL}$, (4) lower low intertidal zone: below -0.7 MTL.

The sites were selected using a stratified random sampling procedure. The uneven number of sites at tidal levels and locations (Table 1) roughly reflects the areal proportions in the Sylt-Røm $\varnothing$ Bight. For practical reasons, 11 sites in the western part of Königshafen Bay were sampled in a straight line (Fig. 2). Because these sites were situated at different tidal levels and on different sediments, they are treated as random samples. At each sampling site the following parameters were recorded: (1) sediment type: sand $(0-10 \%$ of the particle fraction $<0.063 \mathrm{~mm})$ or muddy sand (10-50\% of the particle fraction $<0.063 \mathrm{~mm}$ ) according to the map of Bayerl et al. (1998); (2) A. marina densities based on number of casts per square metre $\left(<5\right.$ ind $\mathrm{m}^{-2}, 5-30$ ind $\mathrm{m}^{-2},>30$ ind $\left.\mathrm{m}^{-2}\right)$; (3) presence or absence of seagrass (Zostera spp.); (4) presence or absence of projecting $M$. arenaria shells (distinct areas where empty shells of $M$. arenaria in living position project out of the sediment).

Sampling of $M$. arenaria adults, death assemblages and bivalve spat

Between 24 May and 29 June 1995 a total of 98 sites on the intertidal flats of Sylt and Rømø were sampled once for adults of $M$. arenaria. A few sites were sampled again in August 1996 and July 1997. At most sites, empty shells still in living position (death assemblages) were also recorded. The same sites plus another 67 (resulting in a total of 165) were sampled for spat between 11 July and 12 September 1995. All sites were visited once except for six permanent sites (three at Rømø, three at East Sylt), sampled fortnightly (around full and new moon) from 11 July until 12 October 1995. In 1996150 sites were sampled again for spat between 18 September and 10 October. A global positioning system (Garmin GPS 50) was used to locate sampling positions. Permanent sites were marked with iron stakes.

\section{Selection of sampling sites}

The intertidal flats were divided into three locations (see Figs 1-3) and four tidal levels: (1) high intertidal zone: above $0.0=$ mean tid-
Sampling technique and size measurement

\section{Adults and death assemblages of $M$. arenaria}

At each site the sediment below $0.1 \mathrm{~m}^{2}$ was sampled using a metal frame $(50 \mathrm{~cm}$ long, $20 \mathrm{~cm}$ wide, $20 \mathrm{~cm}$ deep). The frame was pushed into the sediment and its contents excavated down to $35 \mathrm{~cm}$ with a fork. Live clams and shells were separated from the sediment by hand. At sites where $M$. arenaria signalled its presence by distinct oval siphon holes at the sediment surface, unbiased samples were obtained by throwing the frame a few metres with eyes closed. Between three and five parallels, 1-3 m apart, were taken per site. The death assemblages were obtained from the first subsample only. In the laboratory, live clams and empty shells were counted and the maximum shell length of the left valve measured to the nearest millimetre with a vernier caliper. 


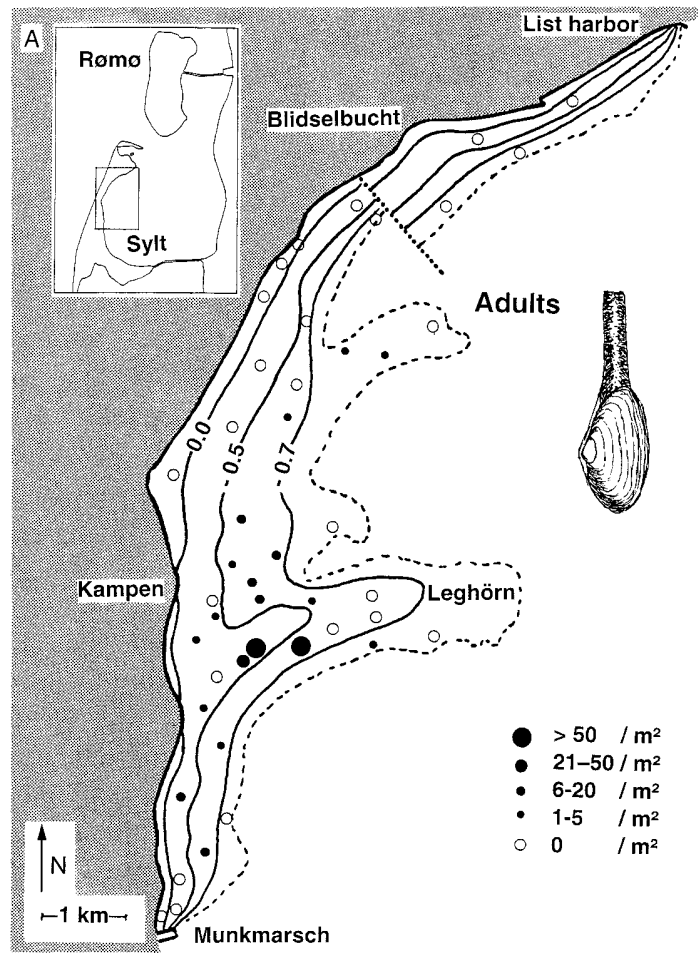

Fig. 3A,B Mean abundance of $M$. arenaria in the intertidal zone of East Sylt, northern Wadden Sea, in 1995. For better visualization of the sampling sites the intertidal zone below the dotted line is enlarged by $50 \%$, above the dotted line by $200 \%$. A Adults; B juveniles. At permanent sites (SI, SII, SIII) abundances are averaged over five sampling dates between July and September 1995

\section{Bivalve spat}

At each site, six sediment cores of $20 \mathrm{~cm}^{2} \times 3 \mathrm{~cm}$ depth were collected randomly within a $9 \mathrm{~m}^{2}$ area using a Perspex tube. At the permanent sites nine or ten cores were taken. Juvenile molluscs were separated from the sediment using a shaking-decantation procedure originally developed for meiofauna (Armonies and Hellwig 1986). Initial sieving through a $0.25-\mathrm{mm}$ screen in July 1995 indicated a minimum spat length of $0.8 \mathrm{~mm}$. Therefore a $0.5-$ $\mathrm{mm}$ screen was used. Sorting, identification and counting of the bivalves were done under a dissecting microscope $(\times 8-80$ magnification). The maximum shell length of $M$. arenaria was measured with a calibrated ocular micrometer. For all statistical computations the program STATISTICA (Statsoft 1994) was used.

\section{Results}

Distribution of abundances in adults and spat

\section{Adults}

The abundance of adult $M$. arenaria ranged from 0 to 243 ind $\mathrm{m}^{-2}$ with a mean of 11.8 ind $\mathrm{m}^{-2}$. A coefficient of variation (calculated as standard deviation/mean) of 3.1 expresses their pronounced patchy distribution (cf. Figs $1-3 \mathrm{~A})$. At 59 sites $(60 \%)$ no live $M$. arenaria were found. At six sites (6\%), the abundance of adult M. arenaria exceeded 50 ind $\mathrm{m}^{-2}$. Two of these sites were locat-

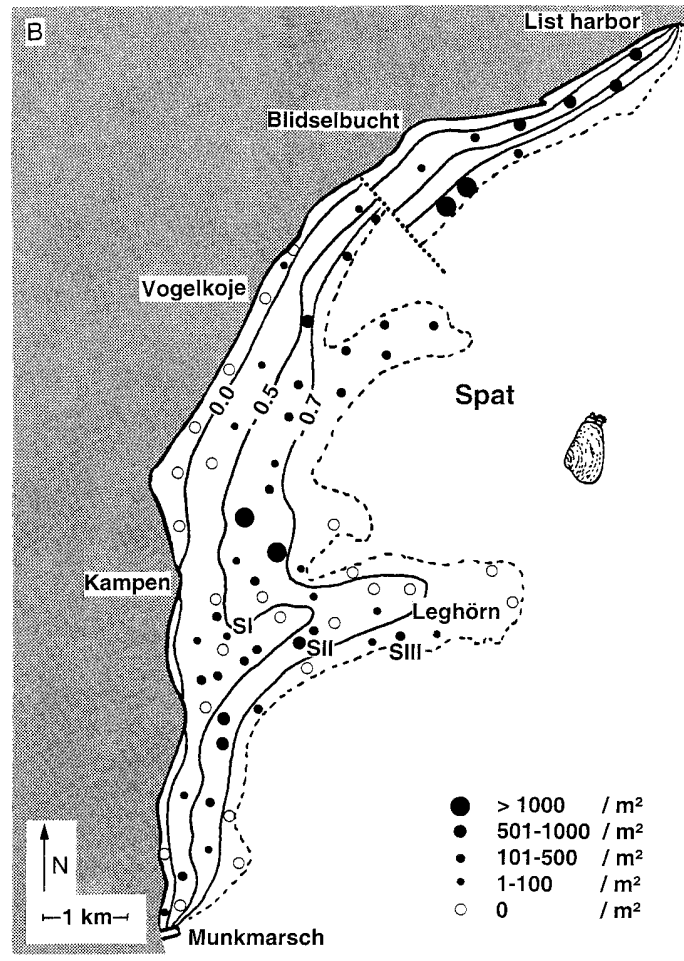

Table 1 Distribution of sampling sites among tidal levels and locations. 165 sites were sampled for $M$. arenaria spat and in parentheses, 98 sites were sampled for adult $M$. arenaria

\begin{tabular}{lcccr}
\hline Tidal level & \multicolumn{2}{l}{ Location } & \multirow{2}{*}{ Total } \\
\cline { 2 - 4 } & Røm $\varnothing$ & Königshafen Bay & East Sylt & \\
\hline High & $9(3)$ & $6(4)$ & $9(5)$ & $24(12)$ \\
Mid & $16(11)$ & $14(12)$ & $23(15)$ & $53(38)$ \\
Upper low & $3(6)$ & $9(8)$ & $22(15)$ & $44(29)$ \\
Lower low & $12(3)$ & $10(6)$ & $22(10)$ & $44(19)$ \\
Total & $50(23)$ & $39(30)$ & $76(45)$ & $165(98)$ \\
\hline
\end{tabular}

ed on the flat called Leghörn at East Sylt (Fig. 3A) and four high density sites were located at Røm $\varnothing$ (Fig. 1A) one near the causeway, two near Tagholm, and one near Østerby. Out of 552 M. arenaria collected from 98 sites, $69 \%$ were from these six sites alone.

\section{Spat}

In 1995 M. arenaria spat occurred at an average abundance of 235 ind $\mathrm{m}^{-2}$, ranging from 0 to 2917 ind $\mathrm{m}^{-2}$. The coefficient of variation of 1.8 indicates an aggregated distribution (cf. Figs 1-3B). At 60 sites (36\%) no $M$. arenaria were found, while abundance exceeded 1000 ind $\mathrm{m}^{-2}$ at 6 sites (4\%). Two of these sites were situated near Tagholm, Rømø (Fig. 1B), two in Blidselbucht and two near Kampen, East Sylt (Fig. 3 B). In each case, two of these sites were located in direct proximity to each other which may be a consequence of high spatfall on a scale larger than intersite distances. 


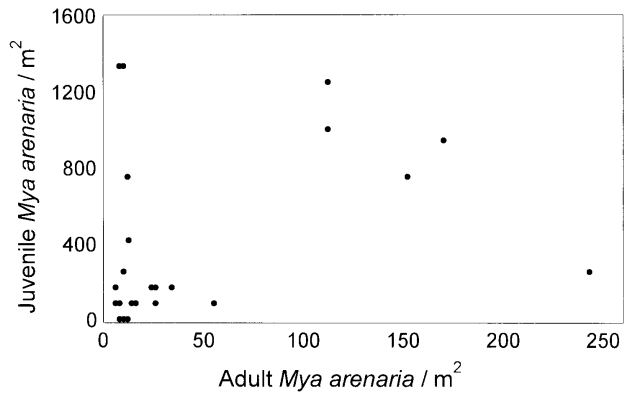

Fig. 4 Abundance of juvenile versus abundance of adult $M$ arenaria per square metre, considering all sites with more than 5 adults $\mathrm{m}^{-2}$. Correlation is not significant (Spearmans $R=0.287, n=25$, $P>0.05)$
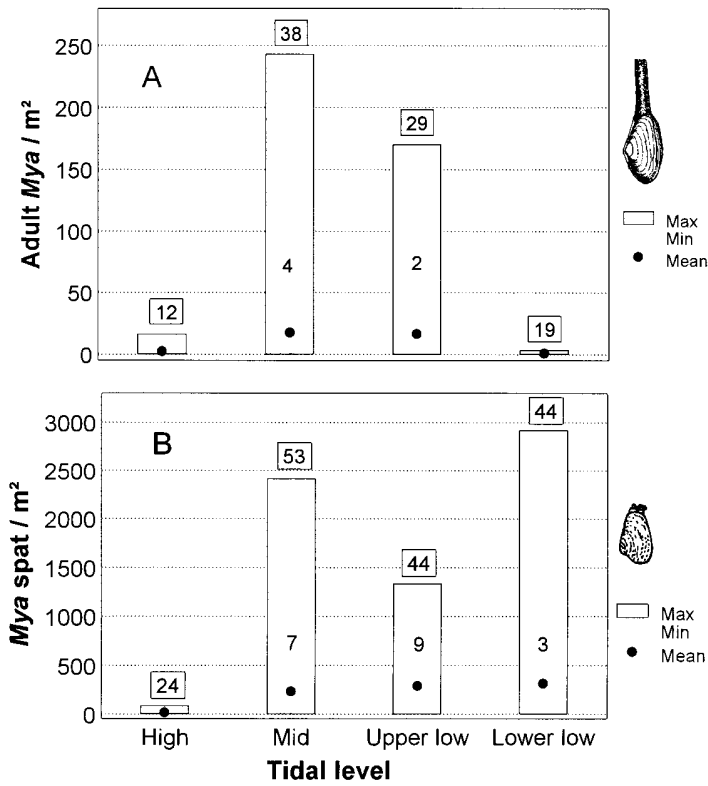

Fig. 5A,B Abundance of $M$. arenaria in relation to tidal level. Indicated are mean (middle point) and minimum/maximum values (box). Number of sampling sites is given over each box. A Adults; number of high density sites $\left(>50\right.$ ind $\left.\mathrm{m}^{-2}\right)$ is given inside each box. B Spat; number of high density sites $\left(>500\right.$ ind $\left.\mathrm{m}^{-2}\right)$ is given inside each box

\section{Comparison of abundances of adults and spat}

The coefficient of variation $(\mathrm{CV})$ as a rough measure of patchiness shows that adult $M$. arenaria $(\mathrm{CV}=3.1)$ were more aggregated than $M$. arenaria spat $(\mathrm{CV}=1.8)$. Considering all sites with abundances $>5$ adults $\mathrm{m}^{-2}$ there was no significant correlation (Spearmans $R=0.287, n=25$, $P>0.05$ ) between adults and spat (Fig. 4). The positive Spearmans $R$ was caused by relatively high abundances of spat (750-1250 ind $\mathrm{m}^{-2}$ ) found at 4 sites with dense beds of adults (112-170 ind $\left.\mathrm{m}^{-2}\right)$. Three of these sites were located at Rømø: two near Tagholm and one near Østerby (Fig. 1). The other site was situated on Leghörn, East Sylt (Fig. 3).
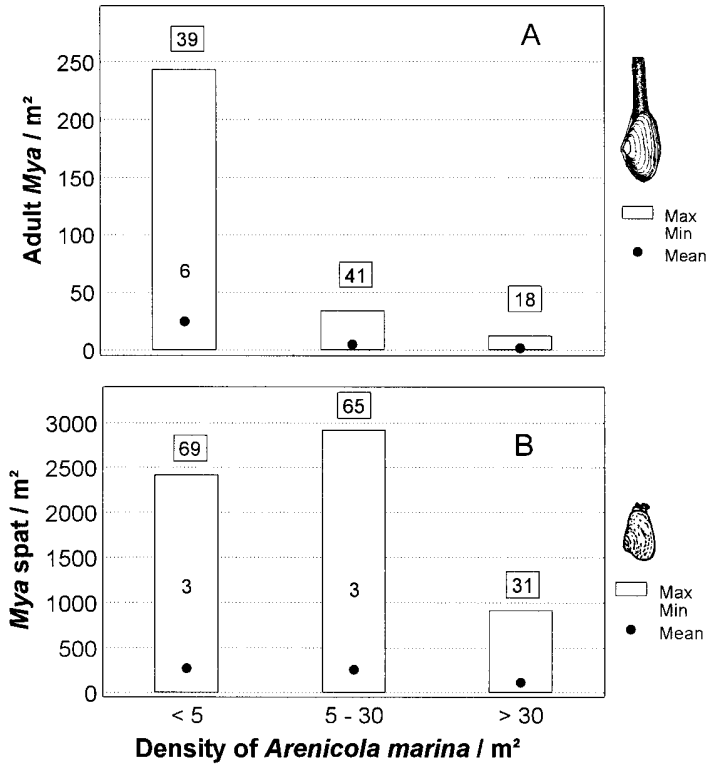

Fig. 6A,B Abundance of $M$. arenaria in relation to three different density classes of Arenicola marina casts. A Adults; number of high density sites $\left(>50\right.$ ind $\left.\mathrm{m}^{-2}\right)$ is given inside each box. B Spat; number of high density sites $\left(>1000\right.$ ind $\left.\mathrm{m}^{-2}\right)$ is given inside each box. For further explanations, see Fig. 5

\section{Tidal level}

Abundances of adult $M$. arenaria differed significantly between tidal levels (H-test, $P<0.001)$. The reason for this difference was a higher abundance in the upper low intertidal zone compared with that in the high intertidal (U-test, $P<0.05)$ and in the lower low intertidal zone $(P<0.001)$. High density patches $\left(>50\right.$ ind $\left.\mathrm{m}^{-2}\right)$ were found in the mid and upper low intertidal zone but not in the high intertidal and the lower low intertidal zone (Fig. 5 A). It cannot be ruled out that the low number of sampling sites at these tidal levels was responsible for the absence of high density patches. However, projecting shell beds - proof of dense $M$. arenaria beds in the past - were found at all tidal levels except in the high intertidal zone.

Abundance of $M$. arenaria spat also differed significantly according to the tidal levels (H-test, $P<0.001$ ). Mean values increased toward the low tide mark, but a significant difference was only found in the high intertidal zone compared with all other tidal zones (U-test, $P<0.001$ ). Likewise, abundances exceeding 500 ind $\mathrm{m}^{-2}$ were found at all tidal levels but not in the high intertidal zone (Fig. 5B). In the mid intertidal zone, the upper low intertidal zone, and the lower low intertidal zone abundances exceeded 500 ind $\mathrm{m}^{-2}$ at least at three sites. So, the low number of sampling sites in the high intertidal zone cannot account for the observed differences in abundance.

\section{Densities of A. marina}

Abundances of adult $M$. arenaria showed no significant difference in relation to densities of A. marina (H-test, 

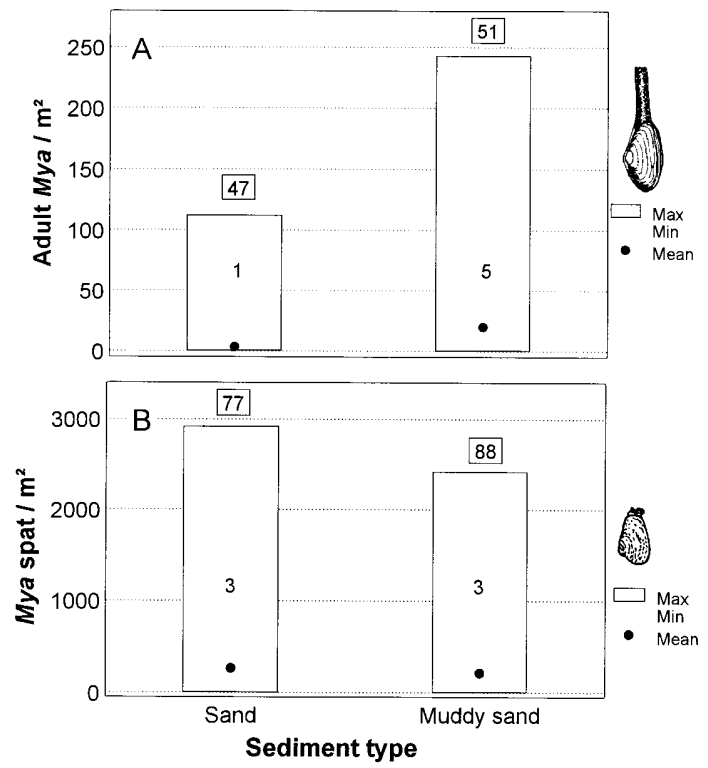

Fig. 7A,B Abundance of $M$. arenaria on sand and muddy sand. A Adults; number of high density sites $\left(>50\right.$ ind $\left.\mathrm{m}^{-2}\right)$ is given inside each box. B Spat; number of high density sites $\left(>1000\right.$ ind $\left.\mathrm{m}^{-2}\right)$ is given inside each box. For further explanations, see Fig. 5

$P>0.05)$. However, all high density patches $\left(>50\right.$ ind $\left.\mathrm{m}^{-2}\right)$ coincided with a virtual absence of lugworms (Fig. 6A). A more complex pattern is shown by $M$. arenaria spat: although abundances were significantly higher at sites with low densities $\left(<5\right.$ ind $\left.\mathrm{m}^{-2}\right)$ of lugworms compared with sites of high densities $\left(>30\right.$ ind $\left.\mathrm{m}^{-2}\right)$ (U-test, $\left.P<0.001\right)$, high density patches of spat $>500$ ind $\mathrm{m}^{-2}$ were found at all lugworm densities, and spat $>1000$ ind $\mathrm{m}^{-2}$ were found only at sites with $<30$ lugworms $\mathrm{m}^{-2}$ (Fig. 6B).

\section{Sediment type and epibenthic structure}

Categorization of all sampling sites into sand and muddy sand showed that abundances of adults were significantly higher on muddy sand than on sand (U-test, $P<0.001$ ). However, high density patches of adults $\left(>50\right.$ ind $\left.\mathrm{m}^{-2}\right)$ were not restricted to muddy sand (Fig. 7A). There was no significant difference in spat abundance $(p>0.05)$ between sand and muddy sand, and the same number of high density patches were found on sand and muddy sand (Fig. 7B).

Only low abundances of $M$. arenaria spat and adults were found at sites with seagrass or projecting $M$. arenaria shells. All sites with seagrass were located in the high or mid intertidal zone. Maximum abundance of spat was 167 ind $\mathrm{m}^{-2}$ (mean 15.3 ind $\mathrm{m}^{-2}$ of 23 sites). Adults were found at a maximum of 5 ind $\mathrm{m}^{-2}$ (mean 1.4 ind $\mathrm{m}^{-2}$ of 12 sites). Projecting $M$. arenaria shells were found at all tidal levels except the high intertidal zone. Maximum abundance of spat was 500 ind $\mathrm{m}^{-2}$ (mean 176.0 ind $\mathrm{m}^{-2}$ of nine sites) and 26 adult $M$. arenaria $\mathrm{m}^{-2}$ (mean 5.8 ind $\mathrm{m}^{-2}$ of five sites). Because of the low number of sampling sites with epibenthic structures no statistical analysis was performed on these parameters.

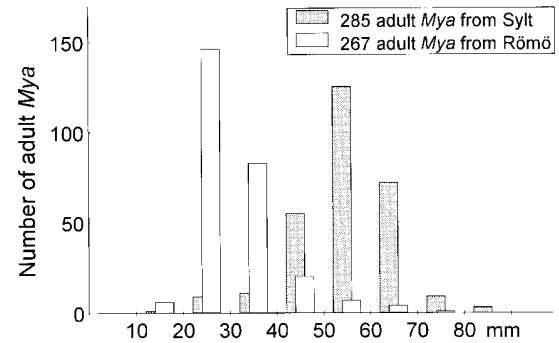

Fig. 8 Length-frequency distribution of adult $M$. arenaria from 75 sampling sites at Sylt (Königshafen Bay and East Sylt combined) and 23 sites at $\mathrm{R} \emptyset \mathrm{m} \emptyset$

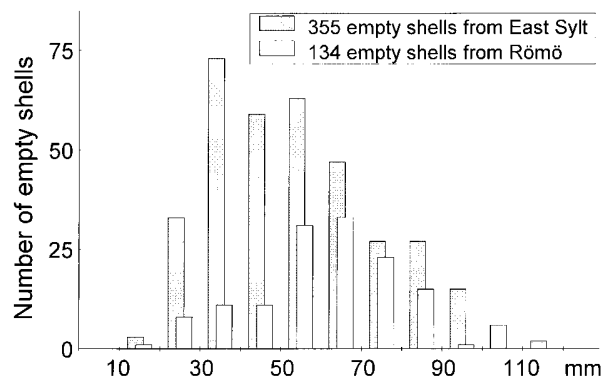

Fig. 9 Length-frequency distribution of empty $M$. arenaria shells (death assemblage) from 43 sampling sites at East Sylt and from 23 sites at $\mathrm{R} \emptyset \mathrm{m} \emptyset$

Distribution of size and age in adults and death assemblage

Shell lengths of living adult clams ranged from 16 to 89 $\mathrm{mm}$ with a mean of $44 \mathrm{~mm}$. The length-frequency distribution of 552 individuals showed two peaks, one between 20 and $30 \mathrm{~mm}$ and the other between 50 and $60 \mathrm{~mm}$. The two peaks stem from different locations (Fig. 8). $M$. arenaria from the northern part of the Bight $(\operatorname{R} \varnothing \mathrm{m} \varnothing)$ with a mean of $32 \mathrm{~mm}$ were significantly smaller than $M$. arenaria from the southern part (Königshafen Bay and East Sylt) with a mean of $55 \mathrm{~mm}$ (KolmogorovSmirnov 2 sample test, $P<0.001)$.

A total of 489 empty $M$. arenaria shells were collected from 66 sampling sites (43 at East Sylt and 23 at Rømø). On average, 83 shells $\mathrm{m}^{-2}$ were found at East Sylt compared with 58 shells $\mathrm{m}^{-2}$ at $\mathrm{R} \emptyset \mathrm{m} \emptyset$. The length-frequency distribution was almost normal, with a peak in the 50-60 $\mathrm{mm}$ size class. Average length was $56 \mathrm{~mm}$ within a range of 14-111 mm. Empty shells from Rømø were significantly larger $(60 \mathrm{~mm})$ than those from East Sylt (Kolmogorov-Smirnov 2-sample test, $P<0.001$ ) (Fig. 9).

The length-frequency distribution of live adult $M$. arenaria strongly suggests that the tidal flats at Røm $\varnothing$ and Sylt were dominated by different cohorts. In order to age the cohort from Røm $\varnothing$, length-frequency distributions of M. arenaria sampled from Tagholm in 19951996 and 1997 were compared (Fig. 10). In 1995 the clams showed a peak in the 25 to $30-\mathrm{mm}$ size class. A year later the majority attained 30 to $45-\mathrm{mm}$. In 1997 a peak was visible in the $35-50 \mathrm{~mm}$ size class. Considering that $M$. arenaria 


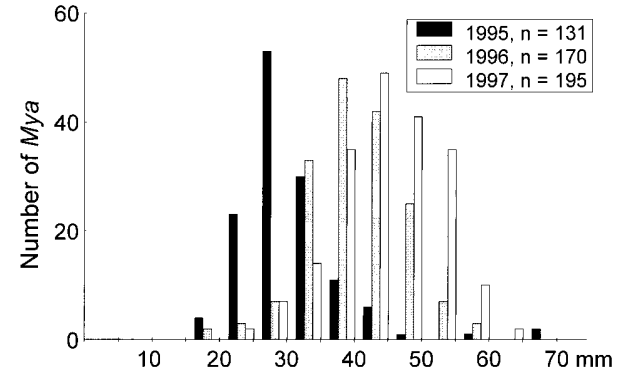

Fig. 10 Length-frequency distribution of $M$. arenaria sampled at Tagholm, Rømø, in June 1995, August 1996, and July 1997

grows fastest in its first years (Brousseau 1978) it is suggested that the $M$. arenaria from Tagholm were 2 years old in 1995 (originating in 1993). The clams from Sylt were larger than the 4-year-olds in 1997, and probably 8-10 years old, originating from the mid-1980s.

Temporal variability of spat

In 1995 spat abundance remained rather constant throughout summer and declined in October. Of the six sites sampled for spat about fortnightly between July and September 1995, two sites were each established at mid intertidal level, at upper low intertidal level and close to the low tide mark (Table 2). The sites in the upper low intertidal zone showed the highest mean abundances of M. arenaria spat (around 1000 ind $\mathrm{m}^{-2}$ ). These two sites were also characterized by high abundances of adults (112 and 170 ind $\mathrm{m}^{-2}$, respectively). Abundance of spat was relatively low at the other sites, especially in the mid intertidal zone. Between July and September a decreasing trend in abundance was only visible at site Sylt II. Here, the abundance of spat differed significantly between the sampling dates (H-test, $P<0.01)$. The other five sites showed no significant difference in spat abundance during July and September $(P>0.2)$. Later in October, abundance also declined at the sites Røm $\varnothing$ II and Røm $\varnothing$ III. The temporal variability between July and October at both Røm $\varnothing$ and Sylt never changed the order of abundance at the sites. Abundance was always highest in the upper low intertidal zone followed by the sites close to the low tide mark and those at mid intertidal level.

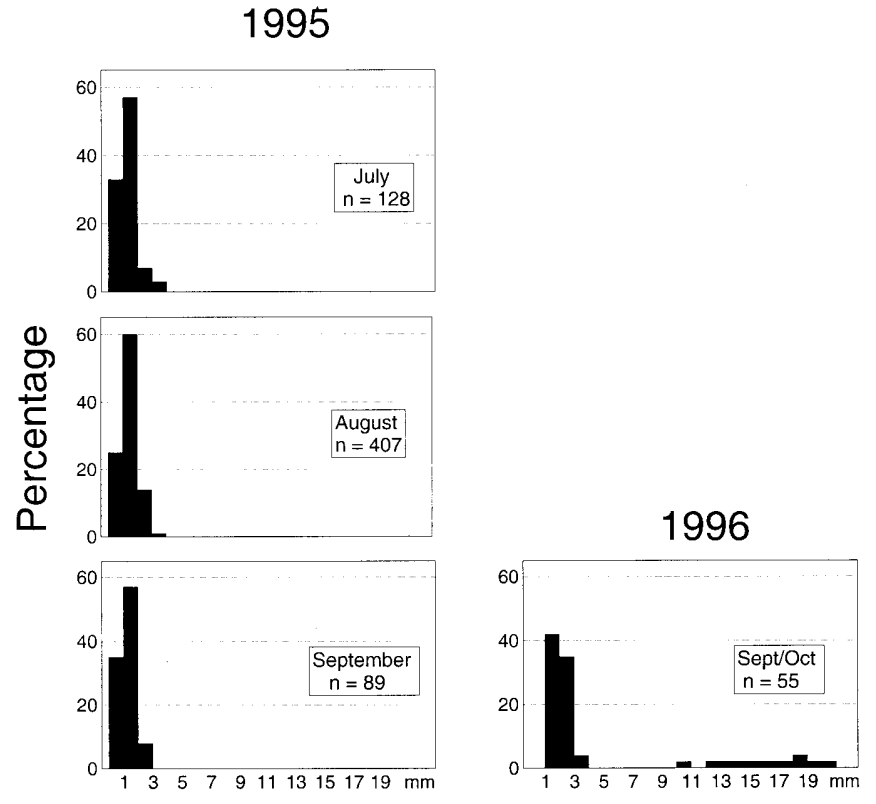

Fig. 11 Length-frequency distribution of M. arenaria spat in 1995 and 1996

In 1995 spat remained small throughout summer, with a maximum size of $4 \mathrm{~mm}$ (Fig. 11). Average size hardly changed between July $(1.4 \mathrm{~mm})$, August $(1.5 \mathrm{~mm})$ and September $(1.3 \mathrm{~mm})$. In all length-frequency distributions there was a marked decline in abundance in the size range 2-3 mm. In 1996 the majority of $M$. arenaria spat were also $<3 \mathrm{~mm}$. However, in this year $18 \%$ of spat attained sizes between 10 and $21 \mathrm{~mm}$ by September.

\section{Discussion}

Sampling intervals and recruitment

A large-scale (20-km) mapping approach was taken to investigate the distribution pattern of $M$. arenaria. A potential drawback of a survey on this scale was the time needed to cover such long distances. As a result, completion of the sampling program took 5 weeks for adult $M$. arenaria and 8 weeks for spat in 1995. According to Brousseau (1978), the survivorship curve of M. arenaria is L-shaped. Mortality is extremely high in both larval and juvenile stages and levels off close to the age of first

Table 2 Abundance $\left(\mathrm{m}^{-2}\right)$ of $M$. arenaria spat (mean of 9-10 sediment cores of $\left.20 \mathrm{~cm}^{2}\right) \pm$ standard error at the six permanent sites at Rømø and East Sylt between July and October 1995

\begin{tabular}{|c|c|c|c|c|c|c|c|c|}
\hline Perm. site & Tidal level & Sediment & 11-12 July & 27-28 July & 10-12 Aug & 29-30 Aug & $11-12$ Sept & $11-12 \mathrm{Oct}$ \\
\hline Rømø I & Mid & Muddy sand & $50 \pm 50$ & 0 & 0 & 0 & $50 \pm 50$ & - \\
\hline $\mathrm{R} \emptyset \mathrm{m} \varnothing \mathrm{II}$ & Upper low & Muddy sand & $1650 \pm 505$ & $450 \pm 240$ & $750 \pm 270$ & $800 \pm 185$ & $1050 \pm 230$ & $150 \pm 75$ \\
\hline $\mathrm{R} ø \mathrm{~m} \varnothing \mathrm{III}$ & Lower low & Muddy sand & $300 \pm 110$ & $56 \pm 50$ & $300 \pm 135$ & $200 \pm 155$ & $350 \pm 150$ & $56 \pm 50$ \\
\hline Sylt I & Mid & Muddy sand & $50 \pm 50$ & $100 \pm 65$ & 0 & $50 \pm 50$ & $50 \pm 50$ & - \\
\hline Sylt II & Upper low & Sand & $900 \pm 235$ & $2150 \pm 350$ & $750 \pm 260$ & $800 \pm 215$ & $400 \pm 180$ & $400 \pm 100$ \\
\hline Sylt III & Lower low & Sand & $150 \pm 75$ & $150 \pm 105$ & $100 \pm 100$ & - & $100 \pm 65$ & $50 \pm 50$ \\
\hline
\end{tabular}


reproduction. Based on these findings, we assume that no bias occurred on adult abundances. In contrast, we expected a steep decline of spat abundances in the course of the summer. However, at most of the regularly sampled sites abundances of spat did not decrease during the 8 -week sampling period (July - September), contradicting results from other studies (e.g. Smidt 1951; Jensen and Jensen 1985; Möller 1986; Günther 1992). Therefore, we assume that the 8-week sampling period adequately depicted spat distribution in summer 1995.

The spatial variability of $M$. arenaria in the SyltRøm $\varnothing$ Bight was characterized by a highly patchy distribution for both spat and adults. A patchy distribution of adults was reported from many areas (the Wadden Sea: e.g. Kühl 1955; east coast North America: e.g. Brousseau 1978). The patchy recruitment pattern of $M$. arenaria is confirmed by Reise (1987) who found a CV of 2.02 in July/August 1979 in the North Frisian Wadden Sea.

\section{No adult-larval interactions}

It was hypothesized that assemblages of filter feeders will have a negative impact on larval settlement because when the water is filtered the larvae will be destroyed (Woodin 1976). This hypothesis is not confirmed by the results of this study because there was a positive, although not significant, correlation between abundances of adults and spat of $M$. arenaria. In fact recruitment was relatively high at sites with high abundances of adults. Although it cannot be ruled out that recruitment would have been even higher at these sites if adults had been absent, the large-scale distribution pattern of spat was clearly not shaped by negative effects of adults. Similar results were also found in other studies in the Wadden Sea (Kühl 1955; Günther 1992) and in North America (Brousseau and Baglivo 1988). In contrast, studies along the Swedish west coast showed a significant negative impact of suspension feeders on the recruitment of total bivalve spat (André and Rosenberg 1991) and M. arenaria (Möller 1986). One must notice that recruitment in the shallow waters of the Swedish investigation areas is usually at least one order of magnitude higher than in the Wadden Sea. It seems possible that very high settlement rates are necessary to be able to detect any negative effects of filter feeders.

\section{Effects of tidal level and of juvenile dispersal}

Abundances of $M$. arenaria spat and adults were low in the high intertidal zone. Spat occurred abundantly at all other tidal levels, with a general increase toward the subtidal, which confirms Reise (1987) who found the same spatial pattern on a $100-\mathrm{km}$ scale. This pattern is in line with the hypothesis of larvae settling passively like inanimate particles (Hannan 1984). In the case of passive sedimentation, larval abundance decreases in a landward direction because of the lower water volume in the high- er intertidal. Alternatively, larvae may have also settled at higher elevations but subsequently disappeared due to mortality or dispersal. However, there was no indication of dispersal in a landward or seaward direction contributing significantly to the distribution pattern of the $M$. arenaria population on a larger scale in the relatively sheltered Sylt-Rømø Bight. At the permanent sites, changes in abundance were irrespective of tidal level and relatively stable between July and September. In addition, settlement of $M$. arenaria did not take place at higher intertidal sites in previous studies in the Wadden Sea (Günther 1992; Armonies 1996). Minimal transport is also suggested by the similar distribution pattern of spat and adults. Dispersal of juvenile M. arenaria may be an important factor on more exposed flats (Matthiesson 1960) as part of bedload sediment transport (Emerson and Grant 1991). In the Sylt-Rømø Bight, stormy weather caused passive displacement with subsequent bedload transport of $M$. arenaria spat onto more exposed sandy flats, while this effect was less important in muddy sediment (Armonies 1998).

\section{Effect of A. marina}

Numbers of $M$. arenaria recruits showed a negative relationship with lugworm densities in the Dutch Wadden Sea (Flach 1992). However, in this study A. marina densities of up to 30 ind $\mathrm{m}^{-2}$ did not prevent high abundances of $M$. arenaria recruits from occupying the same habitat. It remains unclear whether the lack of high abundances of spat at A. marina densities exceeding 30 ind m$^{-2}$ reflected a negative interaction between the two species because large numbers of A. marina were found primarily in higher tidal regions where $M$. arenaria spat abundance was generally low. However, all sampling sites with adult $M$. arenaria of more than 50 ind $\mathrm{m}^{-2}$ were characterized by very low densities of $A$. marina. Incompatibility of $A$. marina and $M$. arenaria beds was also reported by Linke (1939) and Kühl (1951). Perhaps A. marina does not prevent recruitment of $M$. arenaria, but establishment of adult beds is impeded by direct and indirect effects of the lugworm that act on a larger time scale.

Effect of sediment type and epibenthic structure

Five sites with adult abundances $>50$ ind $\mathrm{m}^{-2}$ were located on muddy sand whereas only one site was situated on sand. It cannot be concluded from this that larvae prefer muddy sediments because in 1995 recruitment was independent of sediment type. The region with the highest abundance of spat (Blidselbucht) even consisted entirely of sandy substrates. Furthermore, the conspicuous patchiness of spat does not coincide with a similar patchiness of sediment composition. The independence of M. arenaria with regard to sediment type is confirmed by Smidt (1951), but is contradicted by several other studies (e.g. Emerson et al. 1988). In conclusion, sediment type can- 
not explain the distribution pattern of $M$. arenaria in the Sylt-Rømø Bight.

Blundon and Kennedy's (1982) suggestion of seagrass acting as a refuge for $M$. arenaria spat cannot be confirmed because $M$. arenaria was virtually absent in seagrass. Thus, there is no indication of $M$. arenaria larvae being attracted to seagrass, as found, for example, in Mercenaria mercenaria (Peterson 1986). However, since all sites with seagrass were located in the mid and high intertidal zone, larvae simply may not have reached these habitats.

Sites with projecting $M$. arenaria shells could have shown higher recruitment if larvae were attracted to the remains of their conspecifics. An area that was once suitable for predecessors might have been favoured by substrate-testing larvae. The cause of low recruitment at these sites might be the generally high level of erosion. Without erosion these shells would not have become exposed in the first place.

\section{Mortality and distribution of cohorts}

The 4-mm maximum length of $M$. arenaria spat found in 1995 is in marked contrast to the maximum of $21 \mathrm{~mm}$ found in 1996. In 1995, predators had probably consumed most 0-group $M$. arenaria once they reached a size of 2-3 $\mathrm{mm}$. Consequently, no growth was apparent between July and September 1995. The decline in numbers of spat $>2 \mathrm{~mm}$ coincides with the size of the diet of epibenthic predators. While Crangon crangon cannot prey on bivalves larger than 2 to $3 \mathrm{~mm}$, flounders preyed on $M$. arenaria in the size range $2-12 \mathrm{~mm}$ (Pihl 1982). Plaice and flounder may consume more than 2000 bivalves ( $M$. arenaria and Cerastoderma edule) per $\mathrm{m}^{2}$ per year according to data given by de Vlas (1979). A study in the Danish Wadden Sea suggests that Carcinus maenas played a key role in the elimination of 0-group M. arenaria in 1982 (Jensen and Jensen 1985). In the Sylt-Røm $\varnothing$ Bight settlement of C. maenas was delayed in summer 1996 after the hard winter of 1995/1996 (Strasser, in preparation). These results corroborate the hypothesis that survival is enhanced when spat manage to grow beyond a critical size that protects them from being captured by these main predators (Reise 1985; Möller 1986). As this size was not reached by M. arenaria spat in 1995, no new beds will become established in the subsequent years. An alternative explanation for the lack of larger spat in 1995 would be dispersal into the subtidal. However, as already mentioned, there was no indication of spat dispersal in 1995 . We suggest that recruitment failure in most years due to predation is the reason why the Sylt-Røm $\varnothing$ Bight is colonized mainly by a few cohorts originating in 1993 and the mid 1980s.

However, why is the 1993 cohort found mainly in the northern part of the Bight, while clams from the 1980s are predominantly found in the southern part? One (pre-settlement) explanation is that there is a difference between Rømø (north) and Sylt (south) with regard to larval sup- ply. For $M$. arenaria the majority of larvae are in the plankton at the end of May and the beginning of June (Günther 1992). Stable wind conditions during this period could result in higher larval transport to certain areas of the semi-enclosed Bight. In these areas chances of high recruitment are enhanced if post-settlement mortality is not higher than elsewhere. The similar length-frequency distributions of adult $M$. arenaria in Königshafen Bay and at East Sylt compared with a very different distribution at Rømø support this hypothesis of wind/current dependency, because net larval transport to the south supplies both Königshafen Bay and East Sylt with larvae. Predominant transport of bivalve larvae depending on wind direction was reported by Möller (1986). For the Sylt-Rømø Bight Kopacz (1994) suggested a relation between wind conditions and abundance of gelatinous plankton. Winds from the southwest resulted in higher abundances in the Røm $\varnothing$ Deep than in the Lister Ley, which lies south of Røm $\varnothing$, whereas northeastern winds had the opposite effect.

An alternative (post-settlement) explanation for the different cohorts in Røm $\varnothing$ and Sylt requires the assumption that the strong year class(es) in the mid 1980s survived at Sylt but were eliminated at Rømø. The reverse must have happened to the 1993 year class: M. arenaria was eliminated at Sylt but survived at Røm $\varnothing$. Considering the geographic neighbourhood of Sylt and Røm $\varnothing$, physical disturbance as a factor of differential mortality is not a likely explanation. It is likewise unreasonable to assume that dispersal differed regionally. If predation caused the pattern, the abundance of predators must have been very different at the two locations in the same years and vice versa in other years. Given the high mobility of the predators in question, we regard this as rather unlikely, too. We therefore conclude that differential wind-driven larval supply in some years with subsequent low predation pressure on the benthic juveniles is the most plausible explanation for the observed adult cohorts.

\section{Death assemblages}

The length-frequency distribution of the death assemblages provides information about the size of $M$. arenaria when they died of causes other than predation or displacement (washout). Interpretations of the death assemblages must take into account that the size-frequency distribution may be altered by so-called taphonomic processes such as dissolution, breakage and displacement by bioturbation (Powell et al. 1982) as well as by size selective predation by birds (Cadée 1989). With regard to $M$. arenaria, birds preferably prey on individuals $<45 \mathrm{~mm}$ (Zwarts and Wanink 1989).

The length-frequency distributions of the death assemblages at Røm $\varnothing$ and Sylt (Fig. 9) have in common the virtual absence of the smallest shells $(<20 \mathrm{~mm})$. The lack of small shells is in accordance with the length-frequency distributions of death assemblages of $M$. arenaria collected in the Dutch Wadden Sea (Cadée 1992). The shells $<20 \mathrm{~mm}$ were probably rare because their thin shells are 
more subject to taphonomic processes such as breakage than larger shells. In addition, these size classes undergo heavy predation by crabs and birds; but this cause of mortality is not recorded in the death assemblages. Predation pressure usually ceases when the clams reach a size of $50 \mathrm{~mm}$ because at that point they are able to reach a depth refuge from avian predators (Zwarts and Wanink 1984). Provided predation is the main cause of mortality, one would expect the size classes between $50 \mathrm{~mm}$ and the average size reached at natural death to dominate in the death assemblages. This expected size distribution corresponds exactly to the length-frequency distribution of shells at Rømø. In contrast, the length-frequency distribution of shells from East Sylt showed a peak in the size class 30-40 $\mathrm{mm}$ (Fig. 9), implying that non-predatory mortality played an important role, too. At some sites at East Sylt, high abundances of shells $<50 \mathrm{~mm}$ were found, but live $M$. arenaria were missing. This suggests that some unknown factor killed $M$. arenaria at these sites. Potential causes of mortality may be disturbance, competition or disease. Parasitism appears to have no impact on the population structure of $M$. arenaria in the Wadden Sea because the parasites inherent to populations in North America have not followed the invasion of $M$. arenaria to Europe yet (Lauckner, personal communication).

\section{Conclusions}

Mapping juvenile and adult subpopulations over a wide area, combined with some local information on temporal change, provides a rich source of information on population ecology. Although the precision of detailed local analysis cannot be achieved, the strength of the mapping approach is, when one considers the general picture it presents, that it enables one to separate the rare from the more common phenomena. We therefore believe that the following conclusions are foolproof with regard to errors which may arise when upscaling a rather localized study.

Basically, the population of M. arenaria in the Wadden Sea is centred in the mid and lower tidal zone. This pattern originates from larval settlement. Survival to adulthood is to some extent influenced by sediment properties and the presence of bioturbating lugworms. However, the striking patchiness and dominance of single year classes in the population is the outcome of contingency of events during early lifetime: wind direction during peak larval supply in those years when subsequent predation pressure on the benthic juveniles happens to be low. Larvae neither seem to aggregate at sites with high adult abundances nor do these generally prevent successful recruitment. Once the first year has been survived, M. arenaria cohorts may achieve an age of several years. However, occasional mass mortalities may happen at any time, and their causes have still to be revealed.

Acknowledgements We thank W. Armonies for valuable comments on the manuscript and T. Reinwald for collecting most samples in 1996. M. Strasser was funded by the Hans Böckler Foundation, M. Walensky by the Heinrich Böll Foundation.

\section{References}

André C, Rosenberg R (1991). Adult-larval interactions in the suspension-feeding bivalves Cerastoderma edule and Mya arenaria. Mar Ecol Prog Ser 71:227-234

Armonies W (1994) Drifting meio- and macrobenthic invertebrates on tidal flats in Königshafen: a review. Helgoländer Meeresunters 48:299-320

Armonies W (1996) Changes in distribution patterns of 0-group bivalves in the Wadden Sea: byssus-drifting releases juveniles from the constraints of hydrography. J Sea Res 35:323-334

Armonies W (1998) Driftendes Benthos im Wattenmeer: Spielball der Gezeitenströmungen? In: Gätje C and K. Reise (eds) Ökosystem Wattenmeer, Austausch-, Transport- und Stoffumwandlungsprozesse. Springer, Berlin, Heidelberg, New York pp 473-498

Armonies W, Hellwig M (1986) Quantitative extraction of living meiofauna from marine and brackish muddy sediments. Mar Ecol Prog Ser 29:37-43

Bayerl KA, Köster R, Murphy D (1998) Verteilung und Zusammensetzung der Sedimente im Lister Tidebecken. In: Gätje C, Reise K (eds) Ökosystem Wattenmeer, Austausch-, Transportund Stoffumwandlungsprozesse. Springer, Berlin, Heidelberg, New York pp. 31-38

Beal BF (1989) Biotic and abiotic factors influencing the recruitment of soft-shell clams, Mya arenaria L. to soft-bottom intertidal areas in Downeast Maine, USA. J Shellfish Res. 9:455

Beukema JJ (1982) Annual variation in reproductive success and biomass of the major macrozoobenthic species living in a tidal flat area of the Wadden Sea. Neth J Sea Res 16:37-45

Beukema JJ (1992) Expected changes in the Wadden Sea benthos in a warmer world: lessons from periods with mild winters. Neth J Sea Res 30:73-79

Blundon JA, Kennedy VS (1982) Refuges for infaunal bivalves from blue crab, Callinectes sapidus (Rathbun), predation in Chesapeake Bay. J Exp Mar Biol Ecol 65:67-81

Brousseau DJ (1978) Population dynamics of the soft-shell clam Mya arenaria. Mar Biol 50:63-71

Brousseau DJ, Baglivo JA (1988) Life tables for two field populations of soft-shell clam, Mya arenaria, (Mollusca: Pelecypoda) from Long Island Sound. Fish Bull 86:567-579

Cadée GC (1989) Size-selective transport of shells by birds and its palaeoecological implications. Palaeontology 32:429-437

Cadée GC (1992) Eolian transport and left/right sorting of Mya shells (Mollusca, Bivalvia). Palaios 7:198-202

Emerson CW, Grant J (1991) The control of soft-shell clam (Mya arenaria) recruitment on intertidal sandflats by bedload sediment transport. Limnol Oceanogr 36:1288-1300

Emerson CW, Minchinton TE, Grant J (1988) Population structure, biomass, and respiration of Mya arenaria L. on temperate sandflat. J Exp Mar Biol Ecol 115:99-111

Flach EC (1992) Disturbance of benthic infauna by sediment-reworking activities of the lugworm Arenicola marina. Neth J Sea Res 30:81-89

Gätje C, Reise K (eds) (1998) Ökosystem Wattenmeer, Austausch-, Transport- und Stoffumwandlungsprozesse. Springer, Berlin Heidelberg New York

Günther CP (1990) Zur Ökologie von Muschelbrut im Wattenmeer. Dissertation, University of Bremen

Günther, C.-P (1992) Settlement and recruitment of Mya arenaria L. in the Wadden Sea. J Exp Mar Biol Ecol 159:203-213

Hannan CA (1984) Planktonic larvae may act like passive particles in turbulent near-bottom flows. Limnol Oceanogr 29:11081116

Jensen KT, Jensen JN (1985) The importance of some epibenthic predators on the density of juvenile benthic macrofauna in the Danish Wadden Sea. J Exp Mar Biol Ecol 89:157-174

Kopacz U (1994) Gelatinöses Zooplankton (Scyphomedusae, Hydromedusae, Ctenophora) und Chaetognatha im Sylter Seegebiet. Cuvillier, Göttingen

Kühl H (1951) Über die Siedlungsweise von Mya arenaria. VerhDtsch Zool Ges 25:385-391 
Kühl H (1955) Studien über die Klaffmuschel Mya arenaria. 3. Das Junggut. Arch Fisch Wiss 6:33-44

Kühl, H (1981) Life histories of some important Wadden Sea invertebrates: the sandgaper Mya arenaria. In: Dankers N, Kühl $\mathrm{H}$, Wolff WJ (eds) Invertebrates of the Wadden Sea. Balkema, Rotterdam, 118-119 (Rep Wadden Sea Working Group 4)

Linke O (1939) Die Biota des Jadebusenwattes. Helgoländer Wiss Meeresunters 1:201-348

Matthiesson GC (1960) Intertidal zonation in populations of Mya arenaria. Limnol Oceanogr 5:381-388

Möller P (1986) Physical factors and biological interactions regulating infauna in shallow boreal areas. Mar Ecol Prog Ser 30: 33-47

Möller P, Rosenberg R (1983) Recruitment, abundance and production of Mya arenaria and Cardium edule in marine shallow waters, western Sweden. Ophelia 22:33-55

Peterson CH (1986) Enhancement of Mercenaria mercenaria densities in seagrass beds: is pattern fixed during settlement season or altered by subsequent differential survival? Limnol Oceanogr 31:200-205

Pihl L (1982) Food intake of young cod and flounder in a shallow bay on the Swedish west coast. Neth J Sea Res 15:419-432

Powell EN, Stanton Jr RJ, Cummins H, Staff G (1982) Temporal fluctuations in bay environments - the death assemblage as a key to the past. In: Davis JR (ed) Proceedings of the symposium on recent benthological investigations in Texas and adjacent states. Texas Academy of Science, Austin, Texas, pp 203-232
Reise K (1985) Tidal flat ecology. Springer, Berlin Heidelberg New York

Reise K (1987) Distribution and abundance of small and juvenile macrofauna on the tidal flats in the Frisian Wadden Sea. In: Tougard S, Asbirk S (eds) Proceedings of the $5^{\text {th }}$ international Wadden Sea Symposium. National Forest Nature Agency and Museum and Fishery and Shipping, Esbjerg, pp 7-25

Smidt ELB (1944) The effects of icewinters on marine littoral faunas. Folia Geogr Dan 2(3):1-36

Smidt ELB (1951) Animal production in the Danish Wadden Sea. Medd Dan Fisk Havunders (Ser Fiskeri) 11:1-151

Statsoft (ed) (1994) CSS: Statistica. Statsoft Inc, Tulsa

Vlas J de (1979) Annual food intake by plaice and flounder in a tidal flat area in the Dutch Wadden Sea, with special reference to consumption of regenerating parts of macrobenthic prey. Neth J Sea Res 13:117-153

Woodin SA (1976) Adult-larval interactions in dense infaunal assemblages: patterns of abundance. J Mar Res 34:25-41

Zwarts L, Wanink J (1984) How oystercatchers and curlews successively deplete clams. In: Evans PR, Goss-Custard JD, Hale WG (eds) Coastal waders and wildfowl in winter. Cambridge University Press, Cambridge, pp 69-83

Zwarts L, Wanink J (1989) Siphon size and burying depth in deposit- and suspension-feeding benthic bivalves. Mar Biol 100: $227-240$

Communicated by H.-D. Franke 